\title{
Analysis of the bacterial community in chronic obstructive pulmonary disease sputum samples by denaturing gradient gel electrophoresis and real-time PCR
}

\author{
Dachang $\mathrm{Wu}^{1+}$, Chenxia Hou ${ }^{1 \dagger}$, Yanxia $\mathrm{Li}^{2}$, Zinan Zhao ${ }^{1}$, Jianjun $\mathrm{Liu}^{1}$, Xin $\mathrm{Lu}^{1}$, Xueqi Shang ${ }^{1}$ and Yi Xin ${ }^{1 *}$
}

\begin{abstract}
Background: The Global Initiative defines COPD for chronic obstructive lung disease as an entirely preventable and treatable disease characterized by sputum production, bacterial colonisation, neutrophilic bronchial airway inflammation and poor health status. The World Health Organization (WHO) estimates that COPD will become the fourth-most common cause of death worldwide, just behind ischemic heart disease, cerebrovascular disease and HIV/AIDS, by 2030. The aim of this study was to determine the main structure feature of sputum potentially pathogenic microorganisms in subjects with COPD during the clinical stable state.
\end{abstract}

Methods: We employed a molecular genetics-based investigation of the bacteria community, including DNA isolation, PCR amplification and DGGE profiling. PCR-denaturing gradient gel electrophoresis (DGGE) with universal primers targeting the $\mathrm{V} 3$ region of the $16 \mathrm{~S}$ rRNA gene was employed to characterize the overall COPD patient sputum microbiota composition, and some excised gel bands were cloned for sequencing. Real-time PCR was further utilized to quantitatively analyze the subpopulation of microbiota using group-specific primers targeting Streptococcus pneumoniae, Klebsiella pneumoniae, Pseudomonas aeruginosa.

Results: The DGGE profiles of two groups displayed significant differences between COPD and healthy groups $(P<0.05)$. Real-time PCR revealed significant increases of Streptococcus pneumoniae, Klebsiella pneumoniae and Pseudomonas aeruginosa $(P<0.05)$ in the COPD group compared with the healthy group.

Conclusion: This study revealed strong relationship between alterations of sputum microbiota and COPD. By determining the content of several types of bacteria, we can provide evidence to aid in the diagnosis and treatment of COPD.

\section{Background}

Chronic obstructive pulmonary disease (COPD) is categorized by the severity of the airflow obstruction based on the patient's predicted forced expiratory volume in one second $[1,2]$. COPD involves a variety of pathological processes, such as chronic bronchitis, chronic bronchiolitis and emphysema [3]. These pathological processes may occur individually or in combination. Acute exacerbations are common and occur once to three times per year,

\footnotetext{
* Correspondence: jimxin0295@163.com

${ }^{\dagger}$ Equal contributors

'Biotechnology Department, Dalian Medical University, 9 Western Section, Lvshun South Street, Dalian, P.R. China

Full list of author information is available at the end of the article
}

which leads to most of the observed morbidity and mortality among patients $[3,4]$. Bronchial infection is the most common cause and patients with frequent exacerbations appear to have a more rapid decline in quality of life [5]. In addition, acute exacerbations account for frequent medical visits, hospital admission [6] and death in patients with COPD. A longer-term legacy of an acute exacerbation that is also seen is the persistence of bacteria in the lower airway after an acute exacerbation, which is associated with increased inflammation and can lead to the progressive loss of lung function.

Most COPD exacerbations are infectious and largely either bacterial, though viral pathogens have also been isolated during exacerbations [7]. Haemophilus influenza. 
Strep. pneumoniae, Moraxella catarrhalis and Pseudomonas aeruginosa $[8,9]$ are the most frequently isolated bacterial agents during exacerbations. A large number of studies have indicated that one or more pathogens can be isolated from patients' sputum during exacerbations. In a longitudinal study performed by Sethi and his colleagues of sputum microbiology in moderate to severe category COPD patients with an average FEV1 of 47, COPD exacerbations were commonly observed with new bacterial strains: Haemophilus influenza or Moraxella catarrhalis. This study also demonstrated that a great many instances where sputum microbiology were culture positive even without a clear diagnosis of exacerbation [10].

David Soll [11] defined polymicrobial diseases as those diseases that can occur with organisms from different kingdoms, from different genera within a kingdom and finally from different substrains within a strain. The classification of polymicrobial infection refers to polyviral infections, polybacterial infections, viral and bacterial infections, polymicrobial mycotic infections, and infections resulting from microbe-induced immunosuppression. Typically, polymicrobial infection can lead to a more severe situation than those originated from a single etiologic agent. Polymicrobial infections commonly occur in the oral cavity, the upper and lower airway, and the gastrointestinal tract. More and more diseases have already been defined as polymicrobial. However, there are still many diseases that remain to be proven as polymicrobial. In some cases, polymicrobial diseases are not sensitive to antibiotic treatment. Thus, it is important to identify the etiologic agents for polymicrobial infection and the part that each agent may play in the course of disease.

This study was aimed at characterizing the complex microbial diversity profile of the patient with COPD and healthy individuals. PCR-DGGE analysis provided insight into the overall microbiota community, whereas real-time PCR was used to quantify Streptococcus pneumoniae, Klebsiella pneumoniae, and Pseudomonas aeruginosa to observe changes at the specific genus level.

\section{Methods}

\section{Ethics considerations}

The study was approved by the Medical Ethics Committee of the First Affiliated Hospital of Dalian Medical University (Permit Number: KY2012-36).

\section{Sputum specimen collection}

Twenty subjects (10 COPD patients and 10 healthy volunteers) aged 60-80 years participated in the study. The clinical samples were diagnosed and obtained from the First Affiliated Hospital of Dalian Medical University from August to October 2012. All patients had not received any antibiotic treatment. Written informed consent was obtained from all participants who were treated in compliance with the Helsinki Declaration on the participation of human subjects in medical research. Prior to the investigation, sputum samples were stored at $-80^{\circ} \mathrm{C}$.

\section{DNA extraction}

Prior to DNA extraction, all of the sputum samples were digested and decontaminated with $\mathrm{N}$-acetyl-L-cysteine (NALC)-NaOH. Two volumes of NALC-NaOH solution (4\% $\mathrm{NaOH}, 1.45 \% \mathrm{Na}$-citrate, and $0.5 \% \mathrm{NALC}$ ) were mixed with each sputum specimen in a sterilized test tube for digestion. The mixture was cultured at room temperature for 15 minutes with gentle shaking. Ten volumes of $6.7 \mathrm{mM}$ phosphate buffer solution (PBS, pH 7.4) were added and the mixture centrifuged at 3,000 $\mathrm{x} g$ for 15 minutes at room temperature. The supernatant was discarded, and the pellet washed twice with PBS. Total bacterial DNA was extracted using QIAmp DNA Mini and Blood Mini kits (Qiagen, CA, USA) according to the manufacturer's instructions. Briefly, a 100- $\mu$ l aliquot of the decontaminated sputum specimen was mixed with an equal volume of deionized water and centrifuged for $10 \mathrm{~min}$ at $14,000 \times \mathrm{g}$. The pellet was resuspended in ATL buffer (Qiagen, CA, USA) containing $1 \mathrm{mg} / \mathrm{ml}$ proteinase $\mathrm{K}$ and incubated at $56^{\circ} \mathrm{C}$ for $60 \mathrm{~min}$. Subsequently, two cycles of freeze-thawing were performed to lyse the mycobacterial cells. DNA was purified and collected for further detection. The integrity of the nucleic acids was determined visually by $1 \%$ agarose gels electrophoresis containing ethidium bromide. DNA extraction and PCR amplification were performed in a specific PCR diagnosis room to prevent cross-contamination of nucleic acids.

\section{PCR amplification}

Primers targeting the variable V3 region of $16 \mathrm{~S}$ rRNA gene were applied, and the procedure performed following our previous publicized method [12]. Each $50 \mu \mathrm{l}$ of the PCR reaction mixture contained 20 pmol of each primer, $20 \mathrm{mM}$ of dNTP mixture, $5 \mu \mathrm{l}$ of $10 \times$ Ex Taq buffer $\left(\mathrm{Mg}^{2+}\right.$ plus), $5 \mu$ l of $1 \%$ BSA, $2.5 \mathrm{U}$ of Ex Taq DNA polymerase (TakaRa, Japan), and $2 \mu \mathrm{l}$ of DNA template (approximately $200 \mathrm{ng}$ ). PCR amplification was performed in an automated thermocycler (Thermo USA). The PCR program was as follows: $94^{\circ} \mathrm{C}$ for $5 \mathrm{~min}$; 30 cycles of $94^{\circ} \mathrm{C}$ for $30 \mathrm{~s}, 54^{\circ} \mathrm{C}$ for $30 \mathrm{~s}$, and $72^{\circ} \mathrm{C}$ for $30 \mathrm{~s}$; and lastly, $72^{\circ} \mathrm{C}$ for $7 \mathrm{~min}$. The size of the obtained amplicons was checked through electrophoresis in a $2 \%$ agarose gel containing ethidium bromide. The presence of a 200-bp band on the agarose gel indicated successful amplification.

\section{Denaturing gradient gel electrophoresis and DGGE profiles analysis}

PCR-based DGGE analysis was conducted to rapidly detect microbial community structure, followed by subsequent 
confirmation by $\mathrm{qPCR}$ and DNA sequencing. Briefly, DGGE analysis was performed by a Universal Mutation Detection System (Bio-Rad, USA) with an $8 \%$ polyacrylamide gel containing a 35-65\% gradient of urea and formamide (a 100\% denaturing solution contained 40\% [v/v] formamide and $7.0 \mathrm{mM}$ urea) as reported [13]. The ratio of acrylamide to bisacrylamide was 37.5:1. The electrophoresis was run at $200 \mathrm{~V}$ for $10 \mathrm{~min}$, followed by a constant temperature of $60^{\circ} \mathrm{C}$ at $65 \mathrm{~V}$ for 7 hours. The gels were stained with ethidium bromide solution for $60 \mathrm{~min}$, washed with deionized water, and viewed with a Gel Documentation System (Bio-Rad, USA) and photographed on a UV transilluminator.

The DGGE gel images were analyzed using Phoretix 1D (Single Gel Dendrogram) software (Phoretix, Newcastle upon Tyne, UK) [14]. The analysis took into account the number of bands, their gray intensity and the similarity of DGGE profiles. Similarities were displayed graphically as a dendrogram. The clustering algorithm that was used to calculate the dendrogram was an unweighted pair group method with arithmetic averages (UPGMA) [15]. The Shannon-Weaver index of diversity $\left(H^{\prime}\right)$ has been used to determine the diversity of taxa present in gut microbiota from COPD and healthy groups [16]. As the data were nonuniformly distributed, a nonparametric statistical analysis was performed with the Mann-Whitney $U$ test, where a probability value $P<0.05$ was considered as statistically significant. The nonparametric statistical analysis was performed using SPSS (version 11.5). The evenness (E), which reflected uniformity of the bacterial species distribution, was also computed. The H' and E value were calculated with the following respective formulas: Shannon-Weaver index $\left(\mathrm{H}^{\prime}\right)=-\Sigma(P i)($ In $P i)$; evenness $(\mathrm{E})=\mathrm{H}^{\prime} / \mathrm{In} \mathrm{S} . \mathrm{Pi}$ is the proportion of species/bands for the ith species/band in the sample [17]. $S$ is the number of bands.

\section{DNA sequencing}

To identify some separated and specific bands, a sterile scalpel was used to cut out the bands from polyacrylamide gel under UV illumination. The gel fragments were washed once in $200 \mu \mathrm{l}$ of sterile deionized water and kept in $50 \mu \mathrm{l}$ of sterile water overnight at $4^{\circ} \mathrm{C}$ for diffusion. The extracted gel mix was heated at $90^{\circ} \mathrm{C}$ for $10 \mathrm{~min}$, and $4 \mu \mathrm{l}$ of the solution was taken as the DNA template for re-amplifying by PCR using the original primers without a GC clamp. The PCR program was the same as described previously. After purification, the PCR products were cloned into the PMD18-T Easy vector (TaKaRa, Japan), transformed into competent Escherichia coli Nova blue cells, and screened for positive plasmid insertions according to the manufacturer's instructions. A second PCR was utilized to confirm the successful construction of the recon. The obtained PCR products were purified and sent for sequencing (TaKaRa, Japan). The sequence data were compared directly with those in GenBank by BLAST search (NCBI).

\section{Real-Time PCR}

Streptococcus pneumoniae, Klebsiella pneumoniae, Pseudomonas aeruginosa, the important member groups with their unique characteristics in the sputum, were quantified by real-time PCR using group-specific primers. The reactions were performed in real-time PCR detection system (Agilent, USA). Each $25 \mu \mathrm{l}$ reaction mixture contained $12.5 \mu \mathrm{l}$ of $2 \times$ SYBR Green PCR Mix (TaKaRa, Japan), $1 \mu \mathrm{l}$ of each primer $(20 \mu \mathrm{M})$ (Table 1$), 1 \mu \mathrm{l}$ of sample DNA and $9.1 \mu \mathrm{l}$ of sterile deionized water. The different bacteria did not share the same amplification program. For Streptococcus pneumoniae, the procedure was set as one cycle of $95^{\circ} \mathrm{C}$ for $30 \mathrm{~s}$ and then 40 cycles of $95^{\circ} \mathrm{C}$ for $5 \mathrm{~s}$, $63^{\circ} \mathrm{C}$ for $30 \mathrm{~s}$, and $72^{\circ} \mathrm{C}$ for $50 \mathrm{~s}$. For Klebsiella pneumoniae, the procedure involved one cycle at $94^{\circ} \mathrm{C}$ for $5 \mathrm{~min}, 40 \mathrm{cy}$ cles at $94^{\circ} \mathrm{C}$ for $45 \mathrm{~s}, 54^{\circ} \mathrm{C}$ for $60 \mathrm{~s}$, and $72^{\circ} \mathrm{C}$ for $45 \mathrm{~s}$. For Pseudomonas aeruginosa, the procedure involved in one cycle of $95^{\circ} \mathrm{C}$ for $3 \mathrm{~min}, 40$ cycles at $95^{\circ} \mathrm{C}$ for $15 \mathrm{~s}, 55^{\circ} \mathrm{C}$ for $30 \mathrm{~s}$, and $72^{\circ} \mathrm{C}$ for $30 \mathrm{~s}$. To obtain the melting curve, an extra cycle was performed: $95^{\circ} \mathrm{C}$ for $1 \mathrm{~min}, 55^{\circ} \mathrm{C}$ for $30 \mathrm{~s}$, and $95^{\circ} \mathrm{C}$ for $30 \mathrm{~s}$. A tenfold dilution series of plasmid DNA containing target species DNA was used in each real-time PCR assay to generate standard curves for quantitation of target DNA in test samples. The correlation coefficient values of the standard curves were limited from 0.99 to 1.0. Plasmid standards and samples were assayed simultaneously in three parallel PCR reactions.

\section{Results}

\section{DGGE profiles analysis}

The dominant respiratory microbiota of the COPD and healthy group were show in Figure 1. Lanes 4-10 were samples from the COPD group, whereas lane 1-3 represented those from the healthy individuals. The diversity of respiratory microbiota from two groups was analyzed with the Mann-Whitney $U$ test to compare the Shannon-Weaver indexes of diversity $\left(\mathrm{H}^{\prime}\right)$ of the bands from

Table 1 16S rRNA PCR primers used in real-time PCR

\begin{tabular}{llll}
\hline Bacterium & Primer & Sequence (5'- $\left.\mathbf{3}^{\prime}\right)$ & References \\
\hline Streptococcus pneumoniae & $F$ & ACG CAA CTG ACG & {$[18]$} \\
& & AGT GTG AC & \\
& $R$ & GAT CGC GAC ACC & \\
& GAA CTA AT & \\
Klebsiella pneumoniae & $F$ & GAG GTC GGT GGT & {$[19]$} \\
& TCA AGT C & \\
& $R$ & TCG CAG TAA AGA & \\
Pseudomonas aeruginosa & F & TGG TGG AG & \\
& & ATG GAA ATG CTG & {$[20]$} \\
\hline
\end{tabular}




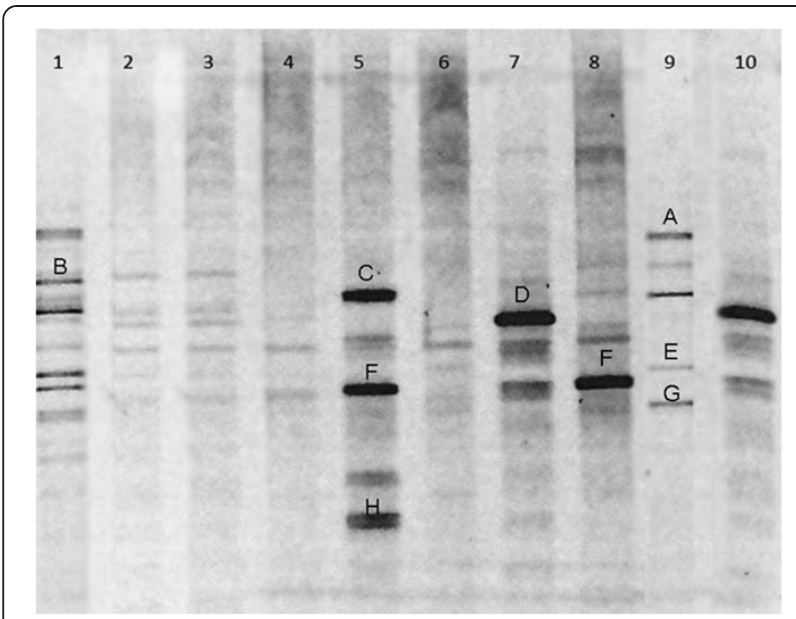

Figure $1 \mathrm{~V} 3$ region of $16 \mathrm{~S}$ rRNA gene profile from COPD group (lane 4-10) and healthy group (lane 1-3) analyzed by DGGE. Bands Bands $A, B, C, D, E, 5 F, 8 F, G$ and $H$ were cut for sequencing.

DGGE profile. It was clearly demonstrated that the diversity in the COPD groups significantly increased compared with healthy groups $(P<0.05)$. The number of bands was richer in the COPD group with a $P$ value of 0.002 by the Mann-Whitney U test. The dendrogram was constructed based on analysis of similarity score and cluster from DGGE profiles by Phoretix 1D software (Figure 2). Two groups formed significant clustering profiles. There were two main clusters in the dendrogram. One was lane $1-3$, related to the healthy group, and the other was lane 4-10 involved in the COPD group. The average number of bands, $\mathrm{H}^{\prime}$ and evenness (E) between the two groups was listed in Table 2. Overall, the respiratory microbiota communities from the COPD group had their own characteristics that were different from those of the healthy group.

\section{Sequence analysis}

Nine bands were selected and cut from the two groups for sequencing in DGGE gels based on quantity analysis (Figure 1). The obtained sequences were further analyzed using a GenBank (NCBI) BLAST search (Table 3). To verify the resolution of DGGE, two adjacent bands from different lanes (5 F, 8 F) were cut and sequenced, and the sequences indicated that both belonged to the Acinetobacter calcoaceticus, indicating that the DGGE gel separated V3 16S rRNA genes from different bacteria effectively. As shown in the black frame from DGGE profile, the COPD group shared a band at the same position, whereas there was nearly no band at the corresponding place in the healthy group. Some separated and strong bands (A, B, C, D, E, G, and H) were identified as Facklamia hominis, Prevotella melaninogenica, Zymomonas mobilis subsp. Mobilis, Nitrosospira multiformis, Streptococcus sp., Bacteroides vulgatus, and Veillonella sp.

\section{Real-time PCR analysis}

Streptococcus pneumoniae, Klebsiella pneumoniae, and Pseudomonas aeruginosa were chosen as typical important pulmonary bacterial groups for further quantitative ananlysis. Streptococcus pneumoniae is a facultatively anaerobic Gram-positive bacterium that normally resides harmlessly within the human nasopharynx but is a major cause of morbidity and mortality worldwide, causing pneumonia. Klebsiella pneumoniae is a Gram-negative bacterium. It is facultatively anaerobic. K. pneumoniae is an important cause of human infections. Infections or diseases are usually nosocomial or hospital-acquired. The diseases caused by $K$. pneumoniae can result in the death of patients who are immunodeficient. Pseudomonas aeruginosa is a Gram-negative bacterium. Pseudomonas aeruginosa is an opportunistic human pathogen. It is always listed as one of the top three most frequent Gram-negative pathogens and is linked to the worst disease outcomes. The copy numbers of each bacterium are shown in Table 4. Streptococcus pneumoniae, Klebsiella pneumoniae and Pseudomonas aeruginosa were increased significantly in the COPD group compared with the healthy group $(P<0.05)$. The data were reported as the average estimate of the logarithms of sputum PCR target genetic amplicon copy numbers present in $1 \mu \mathrm{l}$ of sputum. Results with $P<0.05$ (Mann-Whitney $U$ test) were considered significantly different.

\section{Discussion}

According to our results gained from PCR-DGGE profiling techniques, there were multitude pathogens present in all of the samples, which indicated the high sensitivity of this molecular-based approach. Most of the detected microorganisms were catalogued as uncultured bacteria. However, certain most frequently isolated bacteria were not found, such as Haemophilus spp and Moraxella catarrhalis. In contrast to the routine culture-based approach, in which we usually isolate individual pathogen, it is quite easy to detect multitude microbial pathogens at a high frequency. This notable phenomenon implies that if we intend to define a given respiratory system disease as a polymicrobial infection similar to the cystic fibrosis-associated bronchiectasis, we can employ the more sensitive molecular-based techniques.

With the sputum culture method, most prevalent bacterial isolation was Pseudomonas aeruginosa, which was also identified with PCR-DGGE profiling techniques. This bacterium is able produce mortality in some other serious diseases [21]. A prior investigation suggested that the occurrence of the acute exacerbations did not appear to be correlated with the colonization of Pseudomonas aeruginosa that much. However, the patients who were colonized with Pseudomonas aeruginosa did visit hospitals much more than people who were colonized with 


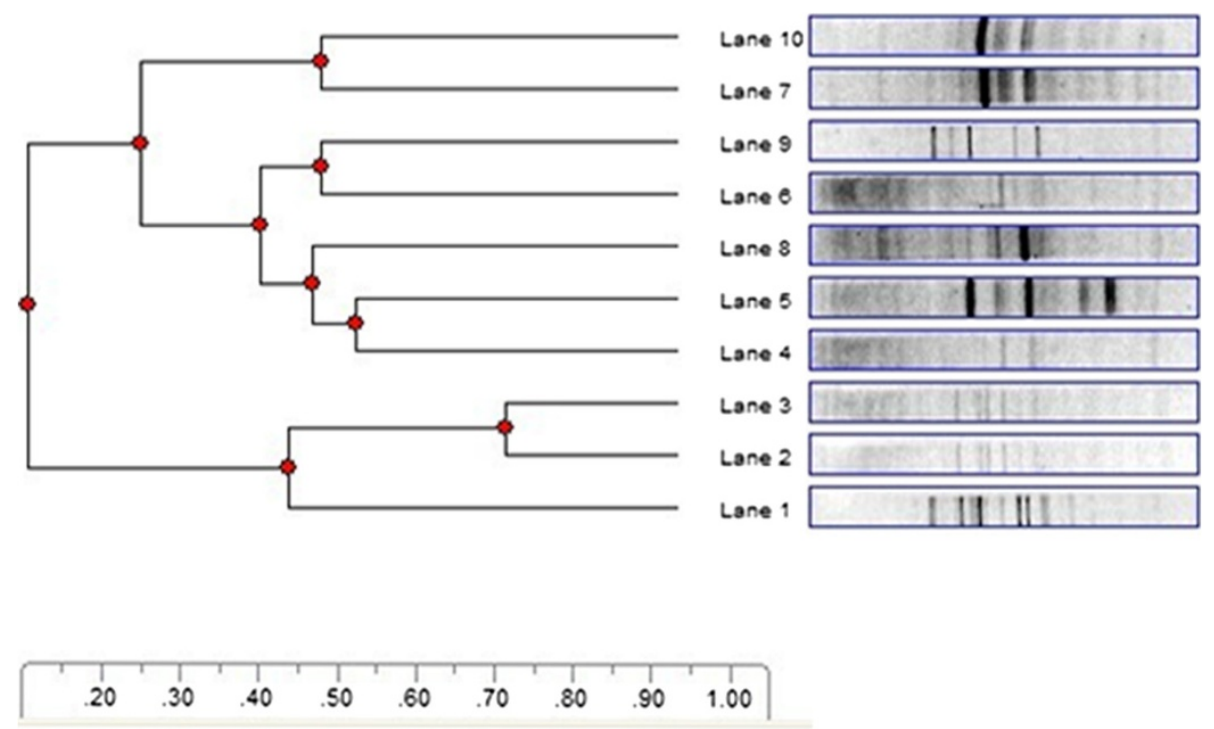

Figure 2 Dendrogram of DGGE profiles analyzed by UPGMA method (COPD group: lane 4-10; healthy group: lane 1-3).

Haemophilus influenza or some other bacteria [22]. In addition, the detection of Pseudomonas aeruginosa in adult samples is much more frequent compared with child samples [23].

Many previous studies have demonstrated that there are some considerable individual variations in the microbial community composition amongst patients. Thus, in our study, we modeled the individual responses to time, with patient as a random effect. As the data had been derived from repeated measures, which was from a subgroup of the sample population. Thus, it provides more accurate information on the underlying polymicrobial infection in sputum samples.

Currently, to analyze bactrial diversity, PCR-DGGE fingerprinting and high-throughput pyrosequencing (NGS) were two important and useful methods, which could matched each other as two molecular analytical methods. Just like all other microbiology methodologies, PCRDGGE fingerprinting, which is a conventional molecular ecological approach, are not free from drawbacks. It has been reported that DGGE only detected the predominant microbiota and its separation has a bias against lowabundance taxa in the community [24]. Muyzer et al.

Table 2 Microbiota diversity index analysis of COPD and healthy group

\begin{tabular}{cccc}
\hline Diversity index & $\begin{array}{c}\text { COPD group } \\
\text { (Mean } \pm \text { SD) }\end{array}$ & $\begin{array}{c}\text { Healthy group } \\
\text { (Mean } \pm \text { SD) }\end{array}$ & $p$ value \\
\hline Number of bands $(S)$ & $14.43 \pm 1.29$ & $7.75 \pm 0.25$ & 0.002 \\
Shannon-Weaver index $\left(H^{\prime}\right)$ & $2.29 \pm 0.24$ & $1.85 \pm 0.19$ & 0.013 \\
Evenness (E) & $0.84 \pm 0.09$ & $0.96 \pm 0.02$ & 0.035 \\
\hline
\end{tabular}

indicated that only the bacterial species that accounted for more than $1 \%$ out of the total microorganism prevalence were identifiable on the DGGE gel [25]. Even so, DGGE was currently considered as one of the few techniques that allowed reproducible visual comparisons of profiles from microbial communities and were successfully applied to a wide variety of microbial ecosystems [26,27]. Pyrosequencing provided a high-throughput approach to analyze the 16S rRNA gene sequences and explore bacterial diversity in different microhabitats deeply, which can compensate for the disadvantage with the PCR-DGGE method in detecting minor populations in microbiota [28]. This technique has been successfully used in various ecosystems including fermented seafood [29], skin [30], chronic wounds, oral microbiota [24] and so on.

In our study, we just aimed to better estimate the diversity of the sputum community of the healthy and COPD

Table 3 Sequence identities of PCR amplicons derived from DGGE gels

\begin{tabular}{lllc}
\hline $\begin{array}{l}\text { Selected } \\
\text { band }\end{array}$ & Blast result & $\begin{array}{l}\text { Bacteria } \\
\text { phylum }\end{array}$ & Similarity (\%) \\
\hline A & Facklamia hominis & Firmicutes & $96 \%$ \\
B & Prevotella melaninogenica & Bacteroidetes & $95 \%$ \\
C & $\begin{array}{l}\text { Zymomonas mobilis subsp. } \\
\text { mobilis }\end{array}$ & $\begin{array}{l}\text { Proteobacteria } \\
\text { D }\end{array}$ & $100 \%$ \\
5 F, 8 F & Acinetrosospira multiformis & Proteobacteria & $100 \%$ \\
E & Streptococcus sp. & Firmicutes & $99 \%$ \\
G & Bacteroides vulgatus & Bacteroidetes & $100 \%$ \\
H & Veillonella sp. & Firmicutes & $99 \%$ \\
\hline
\end{tabular}




Table 4 Quantitation analysis of bacterial populations in
the COPD and healthy group by real-time PCR(Mean \pm SD)
\begin{tabular}{lcccc}
\hline Bacterium & $\begin{array}{c}\text { COPD } \\
\text { group }\end{array}$ & $\begin{array}{c}\text { Healthy } \\
\text { group }\end{array}$ & $\begin{array}{c}\text { Mann-Whitney } \\
\text { T test }(\boldsymbol{p}) \text { value) }\end{array}$ \\
\hline Streptococcus pneumoniae & $9.48 \pm 3.42$ & $1.24 \pm 1.78$ & 0.001 \\
Klebsiella pneumoniae & $34.65 \pm 31.47$ & $6.26 \pm 17.69$ & 0.047 \\
Pseudomonas aeruginosa & $6.19 \pm 1.81$ & $1.44 \pm 3.22$ & 0.008 \\
\hline
\end{tabular}

people, and to identify the key population changes relevant to COPD. We first utilized PCR-DGGE with broad range primers that correspond to the bacterial $16 \mathrm{~S}$ rRNA hypervariable V3 region to investigate the predominant sputum microbiota in these populations. We also quantified the abundance of bacterial subgroups that associated significantly with COPD using quantitative PCR (qPCR). These methods are appropriate to achieve our above purpose. Also, from other related studies, researchers proposed that PCR-DGGE analysis could be used to monitor the dramatic shift of bacterial transition and routinely defined diseases in laboratory [31]. It's economic and convenient. So in some research area for the large-scale screenning of specific bacteria, this mehtod still occupy the important position and widely used.

Recently, little work has been performed to examine the contribution of the lung or lower respiratory tract microbiome on the pathogenesis of pulmonary diseases. Especially in inflammatory lung diseases such as asthma and COPD, the local microbiome may play an important role in the pathogenesis [32]. Purcell etc. analysed polymicrobial airway bacterial communities in adult bronchiectasis patients in sputum samples by culturing and pyrosequencing approaches [33]. Also there are studies about murine lung microbiome in relation to the intestinal and vaginal bacterial communities by culturing and pyrosequencing approaches [32]. Advancements in next generation sequencing technology have provided means for the comprehensive profiling of the microbial community in the respiratory tract in both physiological and pathological conditions. Alexa describe the COPD lung microbiome of 22 patients with moderate or severe COPD compared to 10 healthy control patients. The composition of the lung microbiomes was determined using 454 pyrosequencing of 16S rDNA found in bronchoalveolar lavage fluid (BALF) [34]. The results showed a significant increase in microbial diversity with the development of COPD. The main phyla in all samples were Actinobacteria, Firmicutes, and Proteobacteria. Although our study hold different experimental purposes, adopted different samples and methods compared with this investigation, the results obtained are the same in some degree.

In a summary, for clinical prevention and diagnosis of COPD in the process of introducing this new respiratory tract flora observed targets. Improve the clinical type of high-maintenance rate of pathogenic bacteria, the medication for instruction, is of great significance to improve the treatment effect of COPD.

\section{Conclusion}

This study have provided a relatively comprehensive picture of our current knowledge of the community structure of the COPD sputum bacterial ecosystem and revealed strong relationship between alterations of sputum microbiota and COPD. By determining the content of several types of potential pathogenic populations, we can provide evidence to aid in the diagnosis and treatment of COPD. It is therefore necessary to further study the variations of the respiratory microbiota with the development of COPD.

\section{Competing interests}

The authors declare that they have no competing interests.

\section{Authors' contributions}

This work was carried out in collaboration between all authors. WD, HC and $X Y$ defined the research theme. $\mathrm{HC}$ and WD designed methods and experiments, carried out the laboratory experiments, analyzed the data, interpreted the results and wrote the paper. Other authors co-worked on experiments, discussed analyses, interpretation and presentation. All authors have read and approved the final manuscript.

\section{Acknowledgements}

We would like to thank Li Yanxia and Sun Cuifang from Respiratory Medicine Department, the First Affiliated Hospital of Dalian Medical University for Sample Collection. We also thank faculties from Department of

Biotechnology, Dalian Medical University for their advice and technical supervision of the laboratory procedure.

\section{Author details}

${ }^{1}$ Biotechnology Department, Dalian Medical University, 9 Western Section, Lvshun South Street, Dalian, P.R. China. ${ }^{2}$ Respiratory Medicine Department, The First affiliated hospital of Dalian Medical University, 222 ZhongShan Road, Dalian, P.R. China.

Received: 20 March 2014 Accepted: 30 October 2014 Published: 18 November 2014

\section{References}

1. Anonymous: BTS guidelines for the management of chronic obstructive pulmonary disease. The COPD guidelines group of the standards of care committee of the BTS. Thorax 1997, 52(Suppl):S1-28.

2. Reid PT, Sallenave JM: Cytokines in the pathogenesis of chronic obstructive pulmonary disease. Curr Pharm Des 2003, 9(1):25-38.

3. Burrows $\mathrm{B}$, Earle $\mathrm{RH}$ : Course and prognosis of chronic obstructive lung disease. A prospective study of 200 patients. N Engl J Med 1969, 280(8):397-404.

4. Burge PS: Prevention of exacerbations: how are we doing and can we do better? Proc Am Thorac Soc 2006, 3(3):257-261.

5. Seemungal TAR, Donaldson GC, Paul EA, Bestall JC, Jeffries DJ, Wedzicha JA: Effect of exacerbation on quality of life in patients with chronic obstructive pulmonary disease. Am J Respir Crit Care Med 1998, 157(5):1418-1422.

6. Price LC, Lowe D, Hosker HS, Anstey K, Pearson MG, Roberts CM, British Thoracic S, the Royal College of Physicians Clinical Effectiveness Evaluation: U: UK National COPD Audit 2003: impact of hospital resources and organisation of care on patient outcome following admission for acute COPD exacerbation. Thorax 2006, 61(10):837-842.

7. Sapey E, Stockley RA: COPD exacerbations. 2: aetiology. Thorax 2006, 61(3):250-258 
8. Soler N, Torres A, Ewig S, Gonzalez J, Celis R, El-Ebiary M, Hernandez C, Rodriguez-Roisin R: Bronchial microbial patterns in severe exacerbations of chronic obstructive pulmonary disease (COPD) requiring mechanical ventilation. Am J Respir Crit Care Med 1998, 157(5 Pt 1):1498-1505.

9. Wedzicha JA: Role of viruses in exacerbations of chronic obstructive pulmonary disease. Proc Am Thorac Soc 2004, 1(2):115-120.

10. Sethi S, Evans N, Grant BJB, Murphy TF: New strains of bacteria and exacerbations of chronic obstructive pulmonary disease. New Engl J Med 2002, 347(7):465-471.

11. Brogden KA, Guthmiller JM: Polymicrobial Diseases. In Polymicrobial Diseases: Current and Future Research. Washington (DC): ASM Press; 2002.

12. Liu J, Wu D, Ahmed A, Li X, Ma Y, Tang L, Mo D, Xin Y: Comparison of the gut microbe profiles and numbers between patients with liver cirrhosis and healthy individuals. Curr Microbiol 2012, 65(1):7-13.

13. Walter J, Tannock GW, Tilsala-Timisjarvi A, Rodtong S, Loach DM, Munro K, Alatossava T: Detection and identification of gastrointestinal lactobacillus species by using denaturing gradient gel electrophoresis and speciesspecific PCR primers. Appl Environ Microbiol 2000, 66(1):297-303.

14. Gafan GP, Lucas VS, Roberts GJ, Petrie A, Wilson M, Spratt DA: Statistical analyses of complex denaturing gradient gel electrophoresis profiles. J Clin Microbiol 2005, 43(8):3971-3978.

15. Fromin N, Hamelin J, Tarnawski S, Roesti D, Jourdain-Miserez K, Forestier N, Teyssier-Cuvelle S, Gillet F, Aragno M, Rossi P: Statistical analysis of denaturing gel electrophoresis (DGE) fingerprinting patterns. Environ Microbiol 2002, 4(11):634-643.

16. Silva EP, Russo CAM: Techniques and statistical data analysis in molecular population genetics. Hydrobiologia 2000, 420:119-135.

17. Scanlan PD, Shanahan F, O'Mahony C, Marchesi JR: Culture-independent analyses of temporal variation of the dominant fecal microbiota and targeted bacterial subgroups in Crohn's disease. J Clin Microbiol 2006, 44(11):3980-3988.

18. Aila N, Emler S, Kaijalainen T, De Baere T, Saerens B, Alkan E, Deschaght $P$, Verhelst $R$, Vaneechoutte M: The development of a 16S rRNA gene based PCR for the identification of Streptococcus pneumoniae and comparison with four other species specific PCR assays. BMC Infect Dis 2010, 10(1):1-8.

19. Qin L, Zhou Z, Mu Y, Wu T, Zhou W: Detection of Klebsiella pneumoniae in emulsifiable dust by polymerase chain reaction assay. $J$ Hebei Normal Univ (Nat Sci Ed) 2011, 35(2):192-196.

20. De Vos D, Lim A Jr, Pirnay JP, Struelens M, Vandenvelde C, Duinslaeger L, Vanderkelen A, Cornelis P: Direct detection and identification of Pseudomonas aeruginosa in clinical samples such as skin biopsy specimens and expectorations by multiplex PCR based on two outer membrane lipoprotein genes, oprl and oprL. J Clin Microbiol 1997 35(6):1295-1299.

21. Ho PL, Chan KN, Ip MS, Lam WK, Ho CS, Yuen KY, Tsang KW: The effect of Pseudomonas aeruginosa infection on clinical parameters in steady-state bronchiectasis. Chest 1998, 114(6):1594-1598.

22. Wilson CB, Jones PW, O'Leary CJ, Hansell DM, Cole PJ, Wilson R: Effect of sputum bacteriology on the quality of life of patients with bronchiectasis. Eur Respir J 1997, 10(8):1754-1760.

23. Li AM, Sonnappa S, Lex C, Wong E, Zacharasiewicz A, Bush A, Jaffe A: Non-CF bronchiectasis: does knowing the aetiology lead to changes in management? Eur Respir J 2005, 26(1):8-14.

24. Keijser BJ, Zaura E, Huse SM, van der Vossen JM, Schuren FH, Montijn RC, ten Cate JM, Crielaard W: Pyrosequencing analysis of the oral microflora of healthy adults. J Dent Res 2008, 87(11):1016-1020.

25. Muyzer G, de Waal EC, Uitterlinden AG: Profiling of complex microbial populations by denaturing gradient gel electrophoresis analysis of polymerase chain reaction-amplified genes coding for 16S rRNA. Appl Environ Microbiol 1993, 59(3):695-700.

26. Ledder RG, Gilbert P, Huws SA, Aarons L, Ashley MP, Hull PS, McBain AJ: Molecular analysis of the subgingival microbiota in health and disease. Appl Environ Microbiol 2007, 73(2):516-523.

27. Tresse O, Lorrain MJ, Rho D: Population dynamics of free-floating and attached bacteria in a styrene-degrading biotrickling filter analyzed by denaturing gradient gel electrophoresis. Appl Microbiol Biotechnol 2002, 59(4-5):585-590.

28. Dowd SE, Sun Y, Secor PR, Rhoads DD, Wolcott BM, James GA, Wolcott RD: Survey of bacterial diversity in chronic wounds using pyrosequencing, DGGE, and full ribosome shotgun sequencing. BMC Microbiol 2008, 8:43.
29. Roh SW, Kim KH, Nam YD, Chang HW, Park EJ, Bae JW: Investigation of archaeal and bacterial diversity in fermented seafood using barcoded pyrosequencing. ISME J 2010, 4(1):1-16.

30. Fierer $\mathrm{N}$, Hamady $\mathrm{M}$, Lauber $\mathrm{CL}$, Knight $\mathrm{R}$ : The influence of sex, handedness, and washing on the diversity of hand surface bacteria. Proc Natl Acad Sci U S A 2008, 105(46):17994-17999.

31. Ling Z, Kong J, Liu F, Zhu H, Chen X, Wang Y, Li L, Nelson KE, Xia Y, Xiang C: Molecular analysis of the diversity of vaginal microbiota associated with bacterial vaginosis. BMC Genomics 2010, 11:488.

32. Barfod KK, Roggenbuck M, Hansen LH, Schjorring S, Larsen ST, Sorensen SJ, Krogfelt KA: The murine lung microbiome in relation to the intestinal and vaginal bacterial communities. BMC Microbiol 2013, 13:303-314.

33. Purcell $P$, Jary H, Perry A, Perry JD, Stewart CJ, Nelson A, Lanyon C, Smith DL, Cummings SP, De Soyza A: Polymicrobial airway bacterial communities in adult bronchiectasis patients. BMC Microbiol 2014, 14:130-140

34. Alexa AP, Hyeun Bum K, Cavan SR, Christine W, Richard El: The lung microbiome in moderate and severe chronic obstructive pulmonary disease. PLoS One 2012, 7(10):e47305-e47305.

doi:10.1186/1471-2466-14-179

Cite this article as: Wu et al.: Analysis of the bacterial community in chronic obstructive pulmonary disease sputum samples by denaturing gradient gel electrophoresis and real-time PCR. BMC Pulmonary Medicine 2014 14:179.

\section{Submit your next manuscript to BioMed Central and take full advantage of:}

- Convenient online submission

- Thorough peer review

- No space constraints or color figure charges

- Immediate publication on acceptance

- Inclusion in PubMed, CAS, Scopus and Google Scholar

- Research which is freely available for redistribution 